\title{
İlkokul ve Ortaokul Öğretmenlerinin Duygusal Emek Davranışını Gerçekleştirme Düzeylerinin Çeşitli Değişkenler Açısından İncelenmesi ${ }^{1}$
}

\author{
Dr. Öğr. Üyesi Nuri AKGÜN \\ Bolu Abant İzzet Baysal Üniversitesi, Eğitim Fakültesi, Eğitim Bilimleri Bölümü, Bolu / Türkiye, \\ nuriakgun@hotmail.com, ORCID: 0000-0003-3225-6193
}

Arş. Gör. Ömer YILMAZ*

Bartın Üniversitesi, Eğitim Fakültesi, Eğitim Bilimleri Bölümü, Bartın / Türkiye, omeryilmaz@bartin.edu.tr, ORCID: 0000-0002-0962-2725

\section{$\ddot{\mathbf{O z}}$}

$\mathrm{Bu}$ araștırmanın amacı öğretmenlerin duygusal emek düzeyleri arasında farklılık olup olmadığını belirlemektir. $\mathrm{Bu}$ araştırmada tarama modelinden yararlanılmışıtır. Araştırmaya Bartın şehir merkezindeki ilk ve ortaokullarda çalışan 237 öğretmen oluşturmaktadır. Araştırmada veriler duygusal emek ölçeği aracılıyla toplanmıştır. Verilerin analizinde $t$ Testi ve ANOVA Testi uygulanmıştır. Araştırma sonuçlarına göre öğretmenlerin duygusal emek düzeylerinin orta, rol yapma boyutunun düşük, derinden rol yapma boyutunun yüksek ve doğal duygular boyutunun çok yüksek düzeyde olduğu belirlenmiştir. Öğretmenlerin duygusal emek davranışını gerçekleştirme düzeyleri arasında cinsiyet, meslekî kıdem, yaş, okul türü, eğitim durumu değişkenlerine göre farklılık olduğu belirlenmiştir.

Anahtar Kelimeler: Duygusal emek; Yüzeysel rol yapma; Derinden rol yapma; Doğal duygular; İlkokul öğretmenleri; Ortaokul öğretmenleri.

\footnotetext{
${ }^{1}$ Bu makale, 19-21 Ekim 2017'de Ankara, TOBB ETÜ'de düzenlenen 8. Uluslararası Eğitim Yönetimi Forumu'nda sözlü bildiri olarak sunulan çalışmanın genişletilmiş hâlidir.

* Sorumlu Yazar. Tel: +90 3785011000

Makale Tarih Bilgisi. Gönderim: 30.09.2019, Kabûl: 23.12.2019, Basım: Haziran, 2021

(C) 2021. Kalem Eğitim ve Sağlık Hizmetleri Vakfı. Bütün Hakları Saklıdır. ISSN: 2146-5606, e-ISSN: 2687-6574.
} 


\title{
Investigation of Emotional Labor Behavior Levels of \\ Primary and Secondary School Teachers in Terms of \\ Various Variables
}

\begin{abstract}
The aim of this study is to determine whether there is a significance between the emotional labor levels of teachers. Survey model was used in the study. 237 teachers working in primary and secondary schools in Bartın city center were included in the study. Data were collected through emotional labor scale. $t$ Test and ANOVA Test were used for data analysis. According to the results of the research, it was determined that the emotional labor levels of the teachers were medium, the role-playing dimension was low, the level of deeply acting role was high and the level of real emotions was very high. It was determined that there is a difference between the levels of emotional labor behavior according to the variables of gender, professional seniority, age, type of school and educational status.
\end{abstract}

Keywords: Emotional labor; Role-playing; Deeply acting; Natural emotions; Primary school teachers; Secondary school teachers.

\section{Extended Summary}

\section{Purpose}

The concept of emotional labor was first described by Hochschild (2003). Emotional labor is the regulation of emotions by employees in order to fulfill organizational-based expectations specific to their roles (Brotheridge and Lee, 2003). Emotional labor has been proposed as an aim of being aware that the individual's emotions do not match the situation (Hochschild, 1979). Emotional labor is the display of emotions that the organization wants its employees to show at the moment of their communication with the clients. The feelings that individuals feel are their true feelings. On the other hand, the emotions exhibited are the emotions that the organization wants its employees to do and are deemed appropriate for a particular job. Emotional labor, which is an attitude exhibited during a face-to-face interaction and during a conversation, is defined as the emotions that constitute an important part of the work required by the organization and that the work is required to be exhibited (Akbaş, 2016). According to Hochschild (1979), emotional labor has three different techniques: cognitive, physical, and expression. In cognitive emotional labor, there is an attempt to change opinions, thoughts 
or ideas during the exchange of relevant emotions. In physical emotional labor, there is an effort to change physical symptoms of emotion, such as breathing more slowly, not trying to shake his head. In expressive emotional labor, there is an effort to change the facial expressions that can be seen from the outside in the change of inner emotions such as smiling or crying. Emotional labor contributes significantly to the effect of teaching activities in schools. In addition, the emotional labor behavior that teachers exhibit while performing their duties also increases their success (Beğenirbaş and Meydan, 2012). The aim of the current study is to determine whether the emotional labor levels of the teachers differ according to the variables of education, type of school, working period at school, professional seniority, union membership, age, gender, and marital status.

\section{Method}

In the current study, survey model was used. The participants of the study consist of 237 teachers working in primary and secondary schools of the Ministry of National Education in Bartın city center in 2016-2017 academic year. Teachers in primary and secondary schools in Bartın city center were selected by convenience sampling method. Emotional Labor Scale was applied to the teachers in terms of education level, field, education level, working time at school, professional seniority, union membership, age, gender and marital status. In the process of data collection, a questionnaire consisting of personal information form and emotional labor scale was used as data collection tool. Emotional Labor Scale was developed by Diefendorff, Croyle and Gosserand (2005). The Turkish adaptation of the scale was conducted by Basım and Beğenirbas (2012) and the Turkish Emotional Labor Scale consisted of 13 items. The Cronbach's Alpha coefficient of the Emotional Labor Scale was 0.85 , and 0.90 for role-playing; 0.89 for deeply acting and 0.73 for natural emotions. SPSS was used to analyse and evaluate the collected data. Arithmetic mean and standard deviation scores of the scales were calculated. It was tested that the data were distributed normally for the suitability of the test statistics on the total scores obtained from the scales. Among parametric tests, $t$ Test and ANOVA Test were used.

\section{Results}

It was determined that primary and secondary school teachers' level of emotional labor behavior is medium. When the results related to the sub-dimensions of emotional labor were examined, it was found that the 
role-playing levels of teachers were low, the levels of deeply acting role-playing were high and the level of natural emotions behavior was very high. Emotional labor levels of the teachers showed a meaningful significance according to gender, the type of school, age, seniority, but ther is not a significance in terms of working time in the school, marital status, union membership, educational levels of teachers.

\section{Conclusion and Discussion}

It was concluded that primary and secondary school teachers' realization levels of emotional labor behavior are at the "medium" level. In the literature, Bıyık (2014), Mavi (2015), Akbaş (2016), Ertürk, Keskink1lıç-Kara and Zafer-Güneş (2016), Demircan and Turunç (2017), Cingöz (2018) and Moran (2018) also found that the emotional labor levels of the teachers were at the "medium" level. These results are consistent with the current study's results. According to the results regarding the sub-dimensions of emotional labor, it was determined that teachers' superficial role-playing levels were low. This result of the current study is consistent with the results of the studies of Beğenirbaş and Meydan (2012), Yılmaz, Altınkurt, Güner and Şen (2015), Demircan and Turunç (2017), Alev and Bozbdındır (2018), Erken (2018), Özdemir and Koçak (2018), Şahin (2018) and Y1lmaz-Daban (2018).

\section{Recommendations}

The some recommendations were developed as a result of this research. Teachers' emotional labor behaviors can be examined in depth by using qualitative research technique in future studies. Primary school teachers can be given the opportunity to share emotional labor skills with teachers at the secondary and high school levels through applied workshops. Studies can be conducted in which only high school teachers are sampled or teachers working in all school types are included. In order to gain the emotional labor behaviors required by the teaching profession for young teachers, mentoring programs can be organized where they can teach with experienced teachers for certain periods. With this mentorship from experienced teachers, young teachers will be able to use emotional labor behaviors more beneficially in teaching. Studies that examine the relationships between the concepts of emotional labor and organizational commitment, organizational support, and teaching performance can be conducted. 


\section{Giriş}

Örgütler, sosyal sistemlerdir. Örgütün formal ve informal yanlarının eşit bir biçimde işletilmesi gereklidir. Örgütün formal yanı, örgütün yapı unsurlarını içerir ve formal iletişim yoluyla çalışır. Buna karşılık örgütün informal yanı, kişiler ve gruplar arası ilişkilerden ortaya çıkmaktadır ve informal iletişim aracılıyla işlemektedir. Örgütün informal yanı, sistemin birey boyutunu oluştururken aynı zamanda bireyin kişilik ve ihtiyaçlarını içerir. Ayrıca bu husus bireylerin birer kişiliği olduğunu onaylarken söz, yazı ve davranışlarındaki sınırları yumuşatır. Örgütün formal yanını hiyerarşi, yetki, emir ve denetim gibi kavramlarla işletecek olan yönetici, örgütün informal yanını grup davranışı, bireysel gereksinimler, güdüleme, moral vb. kavramlar aracılıyla çalıştırır (Bursalıoğlu, 2015). Çalışanların iş hayatında yaşamında çalışanların içlerinde yaşadıkları duygular birbirinden farklı olabilir. İş örgütlerinde çalışanlardan beklenen duygular yapılan işe göre değişmektedir. Çalışanlardan göstermeleri istenilen duygular daha çok biçimsel yani formal görünmektedir (Beğenirbaş ve Meydan, 2012). Okullarda ise okul idarecilerinin yeterli düzeyde destek verdiği öğretmenlerin olumlu duygu durumları hissetmeleri (Argon, 2015), örgütsel güven, bağl11ık ve özdeşleşmelerinin artması beklenen bir durum olarak görülmektedir.

\section{Duygusal Emek Kavramı}

$\mathrm{Bu}$ kapsamda bu çalışmada değinilen duygusal emek kavramı ilk kez Hochschild (2003) tarafından tanımlanmıştır. Duygusal emek, çalışanların rollerine özgü örgütsel temelli beklentileri yerine getirmek amaciyla duygularını düzenlemesidir (Brotheridge ve Lee, 2003). Bahsi geçen kavram, bireyin duygularının durumla uyuşmadığının bilincinde olma amacı olarak ileri sürülmüştür (Hochschild, 1979). Duygusal emek, örgütün çalışanlarının hizmet alanlar ile kurdukları iletişim anında göstermelerini istediği duyguların sergilenmesidir. Bireylerin hissettiği duygular onların gerçek duygularıdır. Buna karşın sergilenen duygular örgütün çalışanlarından yapılmasını istediği ve belirli bir iş için uygun görülen duygulardır. Yüz yüze görüşme anında ve konuşma sırasında sergilenen bir tutum olan duygusal emek, ortaya çıkarılması örgüt tarafindan istenen işin önemli bir bölümünü oluşturan ve işin gereği, sergilenmesi çoğunlukla zorunlu olan duygular olarak belirtilmektedir (Akbaş, 2016). Hochschild'a (1979) göre duygusal emeğin üç değişik tekniği vardır. Bunlar bilişsel, fiziksel ve dişavurumsal olarak adlandırılır. Bilişsel duygusal emekte ilgili duyguların değişimi sırasında kanı, düşünce ya da fikirleri değiştirme girişmi vardır. Fiziksel duygusal emekte 
daha yavaş nefes alıp verme, başını sallamamaya çalışma gibi duygunun bedensel ya da fiziksel belirtilerini değiştirme çabası vardır. Dışavurumsal duygusal emekte ise gülümsemek ya da ağlamak gibi içsel duyguların değişiminde dışardan görülebilen yüz ifadelerinin değiştirilmesi çabası vardır. Çalışma yaşamında iş görenlerin hissettiği duyguların gerçekliği örgütün gelişimi ve iyi hizmet üretimi için önemlidir. Örgütten hizmet alanların çalışanlardan kendilerine karşı sergilenen duyguların samimi ve gerçek olmasını hissetmesi, örgüte karşı bakış açısını da etkileyebilmektedir. İnsanların gördükleri muamele ile ilişkili olarak çalışanların onlara gösterdiği duyguların yapmacık olması, bir başka değişle kurumun sergilenmesini istediğini beklediği duyguların çalışanların o an yaşadığ 1 gerçek duygular olmaması, kurumun amaç ve politikalarını başarıya ulaştırmada başarı sağlayabilir ancak kurumdan hizmet alanları gerçek manada memnun etmeyebilir.

\section{Okullarda Duygusal Emek}

Duygusal emek, okullardaki öğretim faaliyetlerinin yeterince etki edebilmesinde önemli katkı sağlamaktadır. Ayrıca öğretmenlerin görevlerini yerine getirirlerken sergilemiş oldukları duygusal emek davranışı aynı zamanda onların başarılarını da artırmaktadır (Beğenirbaş ve Meydan, 2012). Öğretmenlerin eğitim kurumlarında hitap ettikleri kitle öğrenci, veli, diğer öğretmen ve çalışanlardır. Öğretmenlerin bu kitle ile etkileşimi dolayısıyla örgütün amaçlarının daha hedef yönelimli olarak gerçekleşmesi olası görülebilmektedir. Duygusal emek gösterilmesi beklenen mesleklerin belirli özellikleri bulunmaktadır.

Duygusal emek, iş görenlerin hizmet verdikleri kişilerle direkt olarak iletişim kurabildikleri yani etkileşim sağlayabildikleri işlerde, müşterisinin duygu hâline etki edebilmek amaciyla işgörenlerin kendi hislerini kullanabileceği mesleklerde ve örgütün çalışanları üzerinde duygularını denetleme imkânı sağlayan işlerde görülmektedir (Yılmaz-Daban, 2018). Hochschild (1983) duygusal emeği iki temel boyuta ayırmıştır. Birinci boyut yüzeysel rol yapmadır. İş görenlerin gerçekte hissettiği duyguları olduğu gibi sergilemesidir. Bununla birlikte iş görenler duygularını örgütteki duygu gösterim kurallarına göre farklı tarzlarda sergilemektedirler. Diğeri de iş görenlerin sergileme kurallarına uyumlu olabilmek amacıyla göstermek istediği duyguları gerçekte de hissetme hayretinde olduğu derinden rol yapmadır. Duygusal emek araştırmacıları, belirli bir durumda hangi duyguların ifade edilmesi gerektiğini ve hangilerinin gizlenmesi gerektiğini belirleyen toplumsal 
normları temelde uygun duygu sergileme kurallarını düzenleyen davranışsal beklentiler olarak ifade etmektedir. Bir kişi bilinçli olarak uygun olmayan bir duyguyu gizlediğinde ya da durumun gerektirdiği davranışlara uygun düşen sahte duyguları hissediyormuş gibi yaptığında yüzeysel rol davranışında bulunur. Yüzeysel rolün amacı, diğerlerini hissettiğimiz duyguları gerçekten hissettiğimize inandırmaktır (Fein ve Isaacson, 2009). Genellikle izlenim yönetimi olarak adlandırılan yüzeysel rol yapma, insanların yüz ifadelerini, bedensel hareketlerini, ses tonunu ve sosyal olarak arzulanan bazı hislerinveya istenmeyen duyguların varlığını veya yokluğunu sergilemek için belirli sözcükleri yahut cümleleri değiştirdikleri sosyal durumlarda günlük olarak ortaya çıkan yaygın bir durumdur (Rafaeli ve Sutton, 1989). Halka açık bir konuşma yaparken sakin ya da kendinden emin görünmek, gizliden gizliye nefret edilen birini selamlarken samimiyet göstermek veya profesyonel işyerine uygun bir şekilde sergienmesi gereken kurallar yüzeysel rol yapma davranışı örnekleridir. Temel olarak bu örnekler, örgütsel yaşamın davranışsal beklentileri için gerekli görülen profesyonel maskeleri takma yöntemlerimizdir. Maske düşerse bunun maliyetleri olur. Çalışan ile müşteri arasında bir huzursuzluk hissi ya da daha ciddi bir boyutta düşünüldüğünde, uygun olmayan duyguların gösterilmesi nedeniyle profesyonel bir topluluk tarafindan yaptırım uygulanması (Fein ve Isaacson, 2009) yaşanması muhtemel olumsuzluklar olarak düşünülebilir Belli ortamlarda nasıl görünmemiz gerektiğini tanımlayan sergileme kurallarının aksine duygu kuralları çeşitli durumlarda gerçekte neyin hissetmek için uygun olduğunu tanımlar ve bir kişinin esasen hissetmesi gereken duyguları ifade eder (Hochschild, 1979). Örneğin bir doktor, kendi hastasından iğrenmektedir. Doktor, bu davranış1nın gerçek duyguları ile uyumlu olmadığına inanmaktadır. Bu durum, doktor ile hasta arasındaki profesyonel düzeydeki ilişkiyi yöneten duygu düzenleme kurallarını gösterrmektedir (Fein ve Isaacson, 2009). Son olarak iş görenin müşterisine hizmet sunarken gerçek duygular hissetmesi duygusal emeğin doğal boyutunu ifade etmektedir. Burada iş görenin müşteriye karş1 rol yapmadan samimi davranışlar sergileyerek yardımcı olmaya istekli bir hâlde ve olumlu bir tutuma sahip olduğu görülmektedir (Aydın, 2016).

Okul olarak tanımlanan sosyal sistemin en önemli parçalarından biri öğretmendir (Bursalığlu, 2015). Eğitim örgütlerinde eğitim-öğretim hizmetini üretip bunu sunan çalışanlar da öğretmenlerdir. Okullarda öğretmenlerin sunduğu hizmeti alan öğrenciler de eğitim örgütlerinin müşterisi olarak düşünülebilir. Öğretmenlerin öğrencilerine sınıfta ve okulda sergiledikleri 
duyguların gerçek olması yahut okulun sergilenmesini beklediği duygular olması hem okul hem öğrenci hem de öğretmenler için önemlidir. Bununla birlikte öğretmenlik mesleği gittikçe kadınlara özgü bir meslek olarak görülmeye başlanmıştır. Öğretmenliğin değeri toplum içinde kadın statüsündeki değişimlere göre farklılaşabilmektedir. Benzer olarak kadın yöneticiler, toplumun onlara verdiği sınırlı yetkilerden ötürü erkek astları ile olan ilişkilerinde yumuşak davranışlarda bulunmayı yeğlemektedir (Bursalığlu, 2015). Bunun yanı sıra öğretmenlerin kurumlarından gördüğü örgütsel destek ile olumlu öğretim duygu durumları olan onur, haz alma ve umut arasında pozitif bir ilişki varken olumsuz öğretim duygu durumları olan kaygı, öfke ve hayal kırıklığı arasında negatif bir ilişki vardır (Argon ve Yılmaz, 2019). Beğenirbaş ve Meydan'a (2012) göre öğretmenlerin görevlerini gerçekleştirirken sergileyecekleri duygusal emek onların başarısını artırırken okulların etkinliğine de önemli katkılar sağlayabilmektedir. Öğretmenlerden beklenen davranışların bütünü onların sosyal rolünü göstermektedir ve bu rolün önemine verilen değer, öğretmenin statüsü olarak görülebilir. Öğretmenin mesleğine karşı olan tutumunun kaynağı yine öğretmen olmasından ötürü, bu tutum okul içinde ve dişındaki öğelerle olan ilişkilerinde, öğretmenin davranışlarına yön verir (Bursalığlu, 2015).

\section{Araştırmanın Amacı}

$\mathrm{Bu}$ araştırmanın amacı, öğretmenlerin duygusal emek düzeyleri arasında farklılık olup olmadığını belirlemektir. Bu kapsamda aşağıdaki alt problemlere yanıt aranmıştır:

1) Öğretmenlerin duygusal emek düzeyleri nedir?

2) Öğretmenlerin duygusal emek düzeyleri şu değişkenlere göre anlam11 farkl111k göstermekte midir?

- Cinsiyet

- Yaş

- Medeni Durum

- Eğitim Durumu

- Okul Türü

- Meslekî Kidem

- Okulda Çalışma Süresi

- Sendika Üyeliği 


\section{Yöntem}

\section{Araştırmanın Modeli}

$\mathrm{Bu}$ araştırmada tarama modelinden yararlanılmıştır. Tarama modeli, geçmişte yaşanmış olayları yahut şu andaki durumları veya kavramları oluş biçimi ile betimlemeyi amaçlayan araştırma yaklaşımıdır (Karasar, 2000).

\section{Çalışma Grubu}

Araştırmanın çalışma grubunu 2016-2017 eğitim-öğretim yılında Bartın şehir merkezindeki Millî Eğitim Bakanlığı'na bağlı ilkokul ve ortaokullarda görev yapan 237 öğretmen oluşturmaktadır. 2016-2017 eğitim öğretim yılında Bartın şehir merkezindeki Millî Eğitim Bakanlığı'na bağlı ilkokul ve ortaokullarda görev yapan 403 öğretmenin hepsine ölçekler uygulanmıştır. 403 ölçek yalnızca 237 kişi tarafından tamamlandığ için araştırmanın çalışma grubu 237 öğretmenden oluşmaktdır. Araştırmanın çalışma grubunu oluşturan katılımcılara ilişsin kişisel özellikler Tablo 1'de sunulmuştur.

Tablo 1. Katılımcıların Kişisel Özelliklerine Göre Dağılımı

\begin{tabular}{|c|c|c|c|}
\hline Değișkenler & & $\mathbf{F}$ & $\%$ \\
\hline \multirow[b]{2}{*}{ Eğitim Düzeyi } & Lisans & 225 & 94.9 \\
\hline & Lisansüstü & 12 & 5.1 \\
\hline \multirow{2}{*}{ Okul Düzeyi } & İlkokul & 124 & 52.3 \\
\hline & Ortaokul & 113 & 47.7 \\
\hline \multirow{5}{*}{$\begin{array}{l}\text { Okuldaki Çalışma } \\
\text { Süresi }\end{array}$} & $1-5$ Yil & 154 & 65.0 \\
\hline & 6-10 Y1l & 43 & 18.1 \\
\hline & 11-15 Y1l & 24 & 10.1 \\
\hline & 16-20 Y1l & 7 & 3.0 \\
\hline & 20 Y1l ve Üzeri & 9 & 3.8 \\
\hline \multirow{5}{*}{ Meslekî Kıdem } & $1-5$ Yil & 42 & 17.7 \\
\hline & $6-10 Y_{11}$ & 35 & 14.8 \\
\hline & $11-15 Y_{11}$ & 42 & 17.7 \\
\hline & $16-20 Y_{11}$ & 39 & 16.5 \\
\hline & 20 Y1l ve Üzeri & 79 & 33.3 \\
\hline \multirow{5}{*}{ Yaş Aralığ } & $20-25$ & 14 & 5.9 \\
\hline & $26-30$ & 30 & 12.7 \\
\hline & $31-35$ & 39 & 16.5 \\
\hline & $36-40$ & 49 & 20.7 \\
\hline & 40 ve Üzeri & 105 & 44.3 \\
\hline \multirow{2}{*}{ Cinsiyet } & Erkek & 95 & 40.1 \\
\hline & Kadın & 142 & 59.9 \\
\hline \multirow{2}{*}{ Medeni Durum } & Evli & 205 & 86.5 \\
\hline & Bekâr & 32 & 13.5 \\
\hline \multirow{2}{*}{ Sendika Üyeliği } & Var & 141 & 59.5 \\
\hline & Yok & 96 & 40.5 \\
\hline Toplam & & 237 & 100 \\
\hline
\end{tabular}


Araştırmanın çalışma grubunda yer alanların eğitim durumu 225 öğretmen (\%94.9) lisans mezunu, 12 öğretmen (\%5.1) lisansüstü mezunu şeklindedir. Görev türü değişkenine göre 101'i (\%42.6) sinıf öğretmeni, 136's1 \% (57.4) branş öğretmenidir. Görev yapılan okul düzeyi değişkenine göre 124 öğretmen (\%52.3) ilkokullarda, 113 öğretmen (\%47.7) ise ortaokullarda görev yapmaktadır. Öğretmenlerin kendi okullarındaki görev sürelerine bakıldığında 154 öğretmen (\%65.0) kendi okulunda 1-5 y1l arasında görev yapmaktadır. 43 öğretmen (\%18.1) kendi okulunda 6-10 yıl arasında görev yapmaktadır. 24 öğretmen (\%10.1) kendi okulunda 11-15 y1l arasında görev yapmaktadır. 7 öğretmen (\%3.0) kendi okulunda 16-20 yıl arasında görev yapmaktadır. 9 öğretmenin (\%3.8)kendi okulunda görev yapma süresi ise 21 yıl ve üzeri şeklindedir. Öğretmenlerin meslekî kıdemlerine bakıldığında 42 öğretmen (\%17.7) 1-5 yıl arası deneyime, 35 öğretmenin (\%14.8) 6-10 yıl arası deneyime, 42 öğretmen (\%17.7) 11-15 yıl arası deneyime, 39 öğretmen (\%16.5) 16-20 y1l arası deneyime ve 79 öğretmen (\%33.3) 21 yıl ve üzeri deneyime sahip olduğu görülmektedir. Öğretmenlerin yaş aralığı 14 öğretmenin (\%5.9) 20-25 yaş aralığında, 30 öğretmenin (\%12.7) 26-30 yaş aralığında, 39 öğretmenin (\%16.5) 31-35 yaş aralığında, 49 öğretmenin (\%20.7) 36-40 yaş aralığındadır. Araştırmaya katılan öğretmenlerin cinsiyete göre dağılımı 95 erkek (\%40.1) ve 142 (\%59.9) kadın şeklindedir. Medeni durum değişkenine göre 205 öğretmen (\%86.5) evli, 32 öğretmen (\%13.5) bekârdır. Sendika üyeliği değişkenine göre öğretmenlerin 141 'i (\%59.5) sendika üyesidir, 96 öğretmen ise (\%40.5) herhangi bir sendikaya üye değildir.

\section{Veri Toplama Araçları}

Verilerin toplanma sürecinde kullanılan veri toplama araçları kişisel bilgi formu ve Duygusal Emek Ölçeği olmak üzere iki bölümden oluşmaktadır. Birinci bölümde öğretmenlerin eğitim durumu, alanı, görevli olduğu eğitim kademesi, okullarındaki çalışma süresi, meslekî kıdemi, yaşı, cinsiyet ve medeni durumunu içeren kişisel bilgi formu yer almaktadır. İkinci bölümde kullanılan Duygusal Emek Ölçeği ise Diefendorff ve arkadaşları (2005) tarafindan geliştirilmiştir. Bu ölçek için halka hizmet veren (satış, sağlık bakımı, çocuk bakımı ve memurluk gibi) işlerde çalışan 270 lisans öğrencisi örneklem alınmıştır. Ölçekteki alt boyutlar yüzeysel rol yapma, derinden rol yapma ve doğal duygular olmakta üzere üç kısımdan oluşmakta olup yüzeysel rol yapma alt boyutunda 6 , derinden rol yapma alt boyutunda 4 ve doğal davranışlar alt boyutunda ise 3 madde olmak üzere toplam 13 madde yer almaktadır. Türkçeye uyarlama çalışması Basım ve Beğenirbaş 
(2012) tarafindan gerçekleştirilen ölçeğin uygulamasında örneklem olarak iki farklı öğretmen grubu seçilmiştir. Birinci grup Eskişehir'de görev yapan 94 'ü kadın (\%61.8) ve 58'si erkek (\%38.2) olmak üzere toplam 152 ilköğretim okulu öğretmeninden oluşmaktadır. İkinci grup ise Ankara'da ortaöğretim okullarında görevli 117'si kadın (\%42.9) ve 156's1 erkek (\%57.1) olmak üzere toplam 273 öğretmenden oluşmaktadır. 5'li likert tipindeki ölçekte 1'den 5'e kadar olmak üzere "Hiçbir Zaman", "Çok Nadir", "Bazen”, "Çoğu Zaman" ve "Her Zaman" şeklinde seçenekler yer almaktadır. Duygusal Emek Ölçeği'nin değerlendirme aralıkları Tablo 2'de verilmiştir.

Tablo 2. Duygusal Emek Ölçeğinin Değerlendirme Aralıkları

\begin{tabular}{lll}
\hline Aralık & Seçenek & Derece \\
\hline $1.00-1.79$ & (1) Hiçbir zaman & Çok düşük \\
$1.80-2.59$ & (2) Çok nadir & Düşük \\
$2.60-3.39$ & (3) Bazen & Orta \\
$3.40-4.19$ & (4) Çoğu zaman & Yüksek \\
$4.20-5.00$ & (5) Her zaman & Çok yüksek \\
\hline
\end{tabular}

Duygusal Emek Ölçeği'nin güvenirliğini ölçmek için ölçeğin ve alt boyutlarının iç tutarlılıkları hesaplanmış, ölçeğin Cronbach Alfa katsayısı 0.80 olarak bulunmuştur (yüzeysel rol yapma: 0.84; derinden rol yapma: 0.87; doğal duygular: 0.84). Bu çalışmada elden edilen Cronbach Alfa katsayıları Tablo 3'te sunulmuştur.

Tablo 3. Duygusal Emek Ölçeği Güvenirlik Kat Sayıları

\begin{tabular}{lll}
\hline Alt Boyutlar & Madde Sayıs & Cronbach Alfa Katsayıları \\
\hline Duygusal Emek & 13 & 0.85 \\
Yüzeysel Rol Yapma & 6 & 0.90 \\
Derinden Rol Yapma & 4 & 0.89 \\
Doğal Duygular & 3 & 0.73 \\
\hline
\end{tabular}

Tablo 3'e göre bu araştırma için kullanılan Duygusal Emek Ölçeği'nin Cronbach Alfa katsayıs1 0.85, yüzeysel rol yapma boyutunda 0.90 , derinden rol yapma boyutunda 0.89 ve doğal duygular boyutunda 0.73 olarak bulunmuştur. Buna göre Duygusal Emek Ölçeği'nin bu araştırma için güvenilir bir ölçme olduğu söylenebilir.

\section{Verilerin Analizi}

Toplanan verilerin çözümlenmesi ve değerlendirilmesinde SPSS programı kullanılmıştır. Ölçeklerden alınan puanlara ait aritmetik ortalama ve standart sapma puanları hesaplanmıştır. Ölçeklerden alınan toplam puanlar üzerinde yapılan test istatistiklerinin uygunluğunun sağlanabilmesi için 
verilerin normal dağıldığı test edilmiştir. Buna göre parametrik testlerden $t$ Testi ve ANOVA Testi uygulanmıştır.

\section{Bulgular ve Yorum}

Araştırmanın bu bölümünde alt problemlere ilişkin elde edilen bulgulara ve yorumlara yer verilmiştir.

\section{Öğretmenlerin Duygusal Emek Düzeyleri}

Öğretmenlerin duygusal emek davranışını gerçekleştirme düzeylerini belirlemek için kullanılan Duygusal Emek Ölçeğine öğretmenler tarafindan verilen yanıtlara ilişkin aritmetik ortalama ve standart sapma puanları Tablo 4 'te gösterilmiştir.

Tablo 4. Duygusal Emek Ölçeğine İlişkin Aritmetik Ortalama ve Standart Sapma Puanları

\begin{tabular}{lll}
\hline Ölçek ve Alt boyutları & Ortalama & Standart sapma \\
\hline Duygusal Emek & 3.21 & 0.71 \\
Yüzeysel Rol Yapma & 2.32 & 1.09 \\
Derinden Rol Yapma & 3.58 & 1.15 \\
Doğal Duygular & 4.51 & 0.53 \\
\hline
\end{tabular}

Tablo 4 incelendiğinde öğretmenlerin Duygusal Emek Ölçeği’ne verdikleri yanıtların aritmetik ortalaması ölçeğin derecelendirme aralığına göre "orta" düzeyde ( $\bar{x}=3.21$ ) olduğu belirlenmiştir. Öğretmenlerin orta düzeydeki duygusal emek algıları ölçeğin "bazen" seçeneğine karşıllk gelmektedir. Duygusal Emek Ölçeği'nin yüzeysel rol yapma boyutunda öğretmenlerin yanıtları düşük düzeyde ve "çok nadir" seçeneğinde $(\overline{\mathrm{x}}=2.32)$; derinden rol yapma boyutunda "yüksek" düzeyde ve "çoğu zaman" seçeneğinde ( $\overline{\mathrm{x}}=3.58)$; doğal duygular boyutunda ise "çok yüksek" düzeyde ve "her zaman" seçeneğinde $(\overline{\mathrm{x}}=4.51)$ olduğu belirlenmiştir. Buna göre öğretmenlerin duygusal emek davranışını orta derecede yerine getirdikleri görülmektedir. Başka bir ifade ile öğretmenlerin öğretim sırasında sergiledikleri duyguların yönetiminde orta düzeyde çaba gösterdikleri söylenebilir. Düşük düzeyde çıkan yüzeysel rol yapma boyutunda, öğretmenlerin mesleklerini yerine getirdikleri sırada duygularını daha az gizledikleri, öğrencilerine rol yapmadıkları ve çoğunlukla gerçek duygularını yansıttıkları yorumu yapılabilir. Yüksek düzeyde çıkan derinden rol yapma boyutu için öğretmenlerin çoğunlukla hissettikleri duyguları yaşamak için çaba gösterdikleri ifade edilebilir. Çok yüksek düzeyde çıkan doğal duygular boyutunda ise öğretmenlerin öğrencilerine gösterdikleri duyguların samimi ve kendiliğinden ortaya çıkan 
hisler olduğu söylenebilir. Buna göre öğretmenlerin duygusal emek davranışını derinden rol yapma ve doğal duygular boyutlarında büyük oranda yerine getirdikleri, yüzeysel rol yapma boyutunda ise daha az gerçekleştirdikleri görülmüştür.

\section{Öğretmenlerin Duygusal Emek Düzeylerinin Farklı Değişsenlere Göre İncelenmesi}

Araştırmanın ikinci alt problemine ilişkin olarak öğretmenlerin farklı değişkenlere göre duygusal emek düzeylerine dair bulgular aşağıda sunulmuştur.

\section{Cinsiyet}

Cinsiyet değişkenine göre, öğretmenlerin duygusal emek düzeylerini belirlemek için yapılan $t$ Testine ilişkin bulgular Tablo 5 'te sunulmuştur.

Tablo 5. Öğretmenlerin Cinsiyetine Göre Duygusal Emek Ölçeğine İlişkin $t$ Testi Sonuçları

\begin{tabular}{|c|c|c|c|c|c|c|c|}
\hline $\begin{array}{l}\text { Ölçek ve Alt } \\
\text { Boyutları }\end{array}$ & Cinsiyet & $\mathbf{N}$ & $\begin{array}{l}\text { Aritmetik } \\
\text { Ortalama }\end{array}$ & $\begin{array}{l}\text { Standart } \\
\text { Sapma }\end{array}$ & Sd & $\mathbf{T}$ & $p$ \\
\hline \multirow{2}{*}{ Duygusal Emek } & Erkek & 95 & 3.32 & 0.64 & \multirow{2}{*}{235} & \multirow{2}{*}{2.028} & \multirow{2}{*}{$0.044^{*}$} \\
\hline & Kadın & 142 & 3.14 & 0.75 & & & \\
\hline Yüzeysel Rol & Erkek & 95 & 2.54 & 1.09 & \multirow{2}{*}{235} & \multirow{2}{*}{0.256} & \multirow{2}{*}{$0.011^{*}$} \\
\hline Yapma & Kadın & 142 & 2.17 & 1.06 & & & \\
\hline \multirow{2}{*}{$\begin{array}{l}\text { Derinden Rol } \\
\text { Yapma }\end{array}$} & Erkek & 95 & 3.74 & 0.92 & \multirow{2}{*}{235} & \multirow{2}{*}{1.894} & \multirow{2}{*}{0.059} \\
\hline & Kadın & 142 & 3.47 & 1.27 & & & \\
\hline \multirow{2}{*}{ Doğal Duygular } & Erkek & 95 & 4.33 & 0.62 & \multirow{2}{*}{235} & \multirow{2}{*}{-3.967} & \multirow{2}{*}{$0000^{*}$} \\
\hline & Kadın & 142 & 4.62 & 0.42 & & & \\
\hline
\end{tabular}

Tablo 5 incelendiğinde cinsiyet değişkeni etrafinda öğretmenlerin duygusal emek düzeylerini arasında $t$ Testi sonuçlarına göre istatistiksel olarak anlamlı bir farklılık olduğu görülmektedir $(\mathrm{t}=2.02 ; p<.05)$. Buna göre erkek öğretmenlerin duygusal emek davranışını yerine getirme düzeylerinin $(\mathrm{x}=2.02)$ kadın öğretmenlerden daha yüksek olduğu görülmüştür. Duygusal emeğin alt boyutlarına bakıldığında ise cinsiyete göre yüzeysel rol yapma ve doğal duygular boyutlarında anlamlı farklılık olduğu görülmektedir. Erkek öğretmenlerin $(x=2.54)$ yüzeysel rol yapmada kadın öğretmenlere $(x=2.17)$ göre mesleklerini yerine getirirken duygularını daha az gizleyebildikleri, öğrencilerine daha az rol yaptıkları ve gerçek duygularını daha çok yansıttıkları belirlenmiştir. Kadın öğretmenlerin $(\mathrm{x}=4.62)$ ise doğal duygular boyutunda erkek öğretmenlere $(x=4.33)$ nazaran öğrencilerine gösterdikleri duyguların daha samimi ve kendiliğinden oluştuğu ortaya çıkmıştır. 


\section{Yaş}

Yaş değişkenine göre öğretmenlerin duygusal emek düzeylerini belirlemek için yapılan ANOVA Testine ilişkin bulgular Tablo 6'da gösterilmiştir.

Tablo 6. Öğretmenlerin Yaşlarına Göre Duygusal Emek Ölçeğine İlişkin ANOVA Testi

\begin{tabular}{|c|c|c|c|c|c|c|c|}
\hline $\begin{array}{l}\text { Ölçek ve Alt } \\
\text { Boyutları }\end{array}$ & & $\begin{array}{l}\text { Kareler } \\
\text { Toplamı }\end{array}$ & $\begin{array}{c}\text { Serbestlik } \\
\text { Derecesi }\end{array}$ & $\begin{array}{l}\text { Ort. } \\
\text { Kare }\end{array}$ & $p$ & $\mathbf{F}$ & Fark \\
\hline \multirow{3}{*}{$\begin{array}{l}\text { Duygusal } \\
\text { Emek }\end{array}$} & Gruplar Arası & 8.454 & 4 & 2.113 & \multirow{3}{*}{$0.002 *$} & \multirow{3}{*}{4.332} & $20-25$ ve $41^{+}$ \\
\hline & Gruplar İçi & 113.195 & 232 & 0.488 & & & $31-35$ ve $41^{+}$ \\
\hline & Toplam & 121.648 & 236 & & & & \\
\hline \multirow{3}{*}{$\begin{array}{l}\text { Yüzeysel } \\
\text { Rol Yapma }\end{array}$} & Gruplar Aras1 & 20.053 & 4 & 5.013 & \multirow{3}{*}{$0.002 *$} & \multirow{3}{*}{4.451} & \\
\hline & Gruplar İçi & 261.319 & 232 & 1.126 & & & $\begin{array}{l}20-25 \text { ve } 41 \\
31-35 \text { ve } 41^{+}\end{array}$ \\
\hline & Toplam & 281.372 & 236 & & & & \\
\hline \multirow{3}{*}{$\begin{array}{l}\text { Derinden } \\
\text { Rol Yapma }\end{array}$} & Gruplar Aras1 & 11.995 & 4 & 2.999 & \multirow{3}{*}{0.059} & \multirow{3}{*}{2.312} & - \\
\hline & Gruplar İçi & 300.962 & 232 & 1.297 & & & \\
\hline & Toplam & 312.957 & 236 & & & & \\
\hline \multirow{3}{*}{$\begin{array}{l}\text { Doğal } \\
\text { Duygular }\end{array}$} & Gruplar Aras1 & 0.728 & 4 & 0.182 & \multirow{3}{*}{0.632} & \multirow{3}{*}{0.644} & - \\
\hline & Gruplar İçi & 65.606 & 232 & 0.283 & & & \\
\hline & Toplam & 66.335 & 236 & & & & \\
\hline
\end{tabular}

Tablo 6 incelendiğinde öğretmenlerin yaşlarına göre duygusal emek düzeylerini belirlemek için yapılan ANOVA Testi sonuçlarında duygusal emek davranışı ile yüzeysel rol yapma davranışında istatiksel olarak anlamlı bir farklılık olduğu belirlenmiştir $(\mathrm{F}=4.332 ; p<.05)$. Öğretmenlerin yaşları arasındaki bu farklılığın hangi yaş aralığındaki gruplarından kaynaklandığını belirlemek için yapılan Tukey HSD Post Hoc Testi sonuçlarına göre 41 yaş ve üzerinde $(\overline{\mathrm{x}}=3.39)$ olan öğretmenlerin duygusal emek davranışını gerçekleştirme düzeylerinin 20-25 ( $\overline{\mathrm{x}}=2.74)$ ve 31-35 ( $\mathrm{x}=3.00)$ yaş aralığındaki öğretmenlere göre daha yüksek olduğu belirlenmiştir. Yüzeysel rol yapma davranışında da 41 yaş ve üzerinde $(\overline{\mathrm{x}}=2.61)$ olan öğretmenlerin düzeylerinin 20-25 ( $\overline{\mathrm{x}}=1.67)$ ve $31-35(\overline{\mathrm{x}}=2.01)$ yaş aralığındaki öğretmenlere göre daha yüksek olduğu saptanmıştır. Buna göre öğretmenlerin yaşları arttıkça duygusal emek ve yüzeysel rol yapma davranışını gerçekleştirme düzeylerinin de artış gösterdiği görülmüştür.

\section{Medeni Durum}

Medeni durum değişkenine göre öğretmenlerin duygusal emek düzeylerini belirlemek için yapılan $t$ Testine ilişkin bulgular Tablo 7'de verilmiştir. 
Tablo 7. Öğretmenlerin Medeni Durumlarına Göre Duygusal Emek Ölçeğine İlişkin $t$ Testi

\begin{tabular}{|c|c|c|c|c|c|c|c|}
\hline $\begin{array}{l}\text { Ölçek ve Alt } \\
\text { Boyutları }\end{array}$ & $\begin{array}{l}\text { Medeni } \\
\text { Durum }\end{array}$ & $\mathbf{N}$ & $\begin{array}{l}\text { Aritmetik } \\
\text { Ortalama }\end{array}$ & $\begin{array}{c}\text { Standart } \\
\text { Sapma }\end{array}$ & Sd & $\mathbf{T}$ & $p$ \\
\hline Duygusal & Evli & 205 & 3.24 & 0.72 & \multirow{2}{*}{235} & \multirow{2}{*}{1.447} & \multirow{2}{*}{0.155} \\
\hline Emek & Bekar & 32 & 3.05 & 0.68 & & & \\
\hline Yüzeysel Rol & Evli & 205 & 2.36 & 1.10 & \multirow{2}{*}{235} & \multirow{2}{*}{1.485} & \multirow{2}{*}{0.145} \\
\hline Yapma & Bekar & 32 & 2.08 & 0.96 & & & \\
\hline Derinden Rol & Evli & 205 & 3.61 & 1.12 & \multirow{2}{*}{235} & \multirow{2}{*}{0.781} & \multirow{2}{*}{0.439} \\
\hline Yapma & Bekar & 32 & 3.42 & 1.19 & & & \\
\hline Doğal & Evli & 205 & 4.51 & 0.52 & \multirow{2}{*}{235} & \multirow{2}{*}{0.118} & \multirow{2}{*}{0.907} \\
\hline Duygular & Bekar & 32 & 4.50 & 0.54 & & & \\
\hline
\end{tabular}

Tablo 7 incelendiğinde öğretmenlerin medeni durumlarına göre duygusal emek davranışı ile yüzeysel rol yapma, derinden rol yapma ve doğal duygular alt davranışlarını gerçekleştirme düzeylerini belirlemek için yapılan $t$ Testi sonuçlarına göre medeni durumun istatiksel olarak anlamlı bir farklılık ortaya çıkarmadığ 1 belirlenmiştir $(\mathrm{t}=1.44 ; p>.05)$. Buna göre medeni durumun duygusal emek davranışını gerçekleştirmede anlamlı bir fark oluşturmadığı söylenebilir.

\section{Eğitim Durumu}

Eğitim durumu değişkenine göre öğretmenlerin duygusal emek düzeyleri arasında anlamlı bir farklılık olup olmadığını belirlemek için yapılan $t$ Testine ait bulgular Tablo 8'de sunulmuştur.

Tablo 8. Öğretmenlerin Eğitim Durumuna Göre Duygusal Emek Ölçeğine İlişkin $t$ Testi Sonuçları

\begin{tabular}{llcccccc}
\hline $\begin{array}{l}\text { Ölçek ve Alt } \\
\text { Boyutları }\end{array}$ & $\begin{array}{l}\text { Eğitim } \\
\text { Düzeyi }\end{array}$ & $\mathbf{N}$ & $\begin{array}{c}\text { Aritmetik } \\
\text { Ortalama }\end{array}$ & $\begin{array}{c}\text { Standart } \\
\text { Sapma }\end{array}$ & Sd & T & $\boldsymbol{P}$ \\
\hline Duygusal & Lisans & 225 & 3.23 & 0.71 & 235 & 1.368 & 0.196 \\
Emek & Lisansüstü & 12 & 2.95 & 0.67 & & & \\
\hline Yüzeysel & Lisans & 225 & 2.34 & 1.08 & 235 & 1.394 & 0.188 \\
Rol Yapma & Lisansüstü & 12 & 1.88 & 1.11 & & & \\
\hline Derinden & Lisans & 225 & 3.60 & 1.14 & 235 & 1.180 & 0.261 \\
Rol Yapma & Lisansüstü & 12 & 3.18 & 1.20 & & & \\
\hline Doğal & Lisans & 225 & 4.49 & 0.52 & 235 & -1.974 & 0.071 \\
Duygular & Lisansüstü & 12 & 4.77 & 0.47 & & & \\
\hline
\end{tabular}

Tablo 8'e bakıldığında; öğretmenlerin eğitim durumuna göre duygusal emek düzeylerini belirlemek için yapılan $t$ Testi sonuçlarına göre duygusal emek davranış1 $(\mathrm{t}=1.368 ; p>.050)$, yüzeysel rol yapma $(\mathrm{t}=1.394 ; p>.05)$ ve derinden rol yapma $(\mathrm{t}=1.180 ; p>.05)$ alt boyutlarında istatiksel olarak an- 
lamlı bir farklılık olmadığı ancak doğal duygular $(\mathrm{t}=-1.974 ; p<.050)$ alt boyutunda anlamlı bir farklılık olduğu belirlenmiştir. Buna göre öğretmenlerin aldıkları eğitimin doğal duygular sergilemede fark oluşturduğu ve lisansüstü eğitim almış öğretmenlerin $(x=4.77)$ doğal duyguları sergileme düzeylerinin lisans mezunu öğretmenlere $(\mathrm{x}=4.49)$ göre daha yüksek olduğu görülmüştür.

\section{Okul Türü}

Okul türü değişkenine göre öğretmenlerin duygusal emek düzeylerini belirlemek için yapılan $t$ Testi sonuçlarına ilişkin bulgular Tablo 9'da yer almaktadır.

Tablo 9. Öğretmenlerin Görevli Oldukları Okul Düzeyine Göre Duygusal Emek Ölçeğine İlişkin $t$ Testi Sonuçları

\begin{tabular}{llcccccc}
\hline $\begin{array}{l}\text { Ölçek ve Alt } \\
\text { Boyutları }\end{array}$ & $\begin{array}{l}\text { Okul } \\
\text { Türü }\end{array}$ & N & $\begin{array}{c}\text { Aritmetik } \\
\text { Ortalama }\end{array}$ & $\begin{array}{c}\text { Standart } \\
\text { Sapma }\end{array}$ & Sd & T & P \\
\hline Duygusal & İlkokul & 124 & 3.35 & 0.76 & 235 & \multirow{2}{*}{3.074} & \multirow{2}{*}{$0.002^{*}$} \\
Emek & Ortaokul & 113 & 3.07 & 0.63 & & & \\
\hline Yüzeysel & İlkokul & 124 & 2.48 & 1.16 & 235 & 2.472 & $0.014^{*}$ \\
Rol Yapma & Ortaokul & 113 & 2.14 & 0.98 & & & \\
\hline Derinden & İlkokul & 124 & 3.75 & 1.11 & 235 & 2.351 & \multirow{2}{*}{$0.020^{*}$} \\
Rol Yapma & Ortaokul & 113 & 3.40 & 1.16 & & & \\
\hline Doğal & İlkokul & 124 & 4.53 & 0.50 & 235 & 0.819 & \multirow{2}{*}{0.414} \\
Duygular & Ortaokul & 113 & 4.48 & 0.56 & & & \\
\hline
\end{tabular}

Tablo 9 incelendiğinde öğretmenlerin görevli oldukları okul türüne göre duygusal emek davranışını gerçekleştirme düzeylerini belirlemek için yapılan $t$ Testi sonuçlarına göre duygusal emek davranış1 $(\mathrm{t}=3.074 ; p<.05)$; yüzeysel rol yapma $(\mathrm{t}=2.472 ; p<.05)$ ve derinden rol yapma $(\mathrm{t}=2.351 ; p<.05)$ davranışlarında istatiksel olarak anlamlı bir farklılık bulunmuştur. Buna göre ilkokullarda görev yapan öğretmenlerin $(x=3.35)$ ortaokullarda görev yapan öğretmenlere $(x=3.07)$ göre duygusal emek davranışını gerçekleştirme düzeylerinin daha yüksek olduğu belirlenmiştir. Duygusal emeğin alt boyutlarındaki farklılıklara bakıldığında ise ilkokul ögretmenlerinin $(x=2.48)$ yüzeysel rol yapma davranışını gerçekleştirme düzeylerinin ortaokul öğretmenlerine $(\mathrm{x}=2.14)$ göre daha yüksek olduğu saptanmış; yine ilkokul öğretmenlerinin $(x=3.75)$ derinden rol yapma davranışını gerçekleştirme düzeylerinin ortaokul öğretmenlerine $(x=3.40)$ göre daha yüksek olduğu belirlenmiştir.

\section{Meslekî Kıdem}

Meslekî kıdem değişkenine göre öğretmenlerin duygusal emek dü- 
zeylerini belirlemek için yapılan ANOVA Testine ilişkin bulgular Tablo 10 'da gösterilmiştir.

Tablo 10. Öğretmenlerin Meslekî Kıdemlerine Göre Duygusal Emek Ölçeğine İlişkin Anova Testi Sonuçları

\begin{tabular}{|c|c|c|c|c|c|c|c|}
\hline \multicolumn{2}{|c|}{ Ölçek ve Alt Boyutları } & $\begin{array}{c}\text { Kareler } \\
\text { Toplamı }\end{array}$ & $\begin{array}{c}\text { Serbestlik } \\
\text { Derecesi }\end{array}$ & $\begin{array}{l}\text { Ort. } \\
\text { Kare }\end{array}$ & $\mathbf{F}$ & $P$ & Fark \\
\hline \multirow{3}{*}{$\begin{array}{l}\text { Duygusal } \\
\text { Emek }\end{array}$} & Gruplar Aras1 & 7.799 & 4 & 1.950 & \multirow[t]{3}{*}{3.973} & \multirow[t]{3}{*}{$0.004 *$} & \multirow{3}{*}{$\begin{array}{l}1-5 \text { ve } 20 \mathrm{Y}_{1} 1^{+} \\
6-10 \text { ve } 20 \mathrm{Y}_{11}\end{array}$} \\
\hline & Gruplar İçi & 113.849 & 232 & 0.491 & & & \\
\hline & Toplam & 121.648 & 236 & & & & \\
\hline \multirow{3}{*}{$\begin{array}{l}\text { Yüzeysel } \\
\text { Rol } \\
\text { Yapma }\end{array}$} & Gruplar Aras1 & 17.284 & 4 & 4.321 & \multirow[t]{3}{*}{3.796} & \multirow[t]{3}{*}{$0.005^{*}$} & \multirow{3}{*}{$\begin{array}{l}1-5 \text { ve } 20 \mathrm{Y}_{11}+ \\
6-10 \text { ve } 20 \mathrm{Y}_{11}\end{array}$} \\
\hline & Gruplar İçi & 264.088 & 232 & 1.138 & & & \\
\hline & Toplam & 281.372 & 236 & & & & \\
\hline \multirow{3}{*}{$\begin{array}{l}\text { Derinden } \\
\text { Rol } \\
\text { Yapma }\end{array}$} & Gruplar Aras 1 & 9.393 & 4 & 2.348 & \multirow[t]{3}{*}{1.795} & \multirow[t]{3}{*}{0.131} & \multirow[t]{3}{*}{ - } \\
\hline & Gruplar İçi & 303.564 & 232 & 1.308 & & & \\
\hline & Toplam & 312.957 & 236 & & & & \\
\hline \multirow{3}{*}{$\begin{array}{l}\text { Doğal } \\
\text { Duygular }\end{array}$} & Gruplar Aras1 & 0.143 & 4 & 0.036 & \multirow[t]{3}{*}{0.126} & \multirow[t]{3}{*}{0.973} & \multirow[t]{3}{*}{ - } \\
\hline & Gruplar İçi & 66.191 & 232 & 0.285 & & & \\
\hline & Toplam & 66.395 & 236 & & & & \\
\hline
\end{tabular}

Tablo 10 incelendiğinde öğretmenlerin meslekî kıdemlerine göre duygusal emek davranış düzeylerini belirlemek için yapılan ANOVA Testi sonuçlarına göre duygusal emek davranışına $(\mathrm{F}=3.973 ; p<.05)$ ve yüzeysel rol yapma alt boyutunda $(\mathrm{F}=3.796 ; p<.05)$ istatiksel olarak anlamlı bir farkl1lık olduğu bulunmuştur. Duygusal emek davranışı ve yüzeysel rol yapma davranışındaki anlamlı farklılığın hangi gruplar arasında oluştuğunu belirlemek için yapılan Post-Hoc Tukey analizi sonuçlarına göre 20 yıl ve üzeri $(\overline{\mathrm{x}}=3.45)$ meslekî kıdeme sahip öğretmenlerin 1-5 yıl ( $\overline{\mathrm{x}}=3.05)$ ve 6-10 yıl $(\overline{\mathrm{x}}=2.97)$ arası meslekî kıdeme sahip öğretmenlere nazaran duygusal emek davranışlarının daha yüksek olduğu belirlenmiştir. 20 yıl ve üzeri $(\overline{\mathrm{x}}=2.66)$ meslekî k1deme sahip öğretmenlerin $1-5$ y1l $(\overline{\mathrm{x}}=2.03)$ ve $6-10$ y1l $(\overline{\mathrm{x}}=1.99)$ arası meslekî kıdeme sahip öğretmenlere göre yüzeysel ol yapma davranışlarının daha yüksek olduğu saptanmıştır. Buna göre öğretmenlerin meslekî kıdemi arttıkça duygusal emek ve yüzeysel rol yapma davranışını gerçekleştirme düzeyinin de artış gösterdiği söylenebilir.

\section{Okulda Çalışma Süresi}

Öğretmenlerin görev yaptıkları okuldaki çalışma sürelerine göre duygusal emek düzeylerini belirlemek için yapılan Tek Yönlü Varyans Analizi (One Way ANOVA) testine ilişkin bulgular Tablo 11'de gösterilmiştir. 
Tablo 11. Öğretmenlerin Görev Yaptıkları Okuldaki Çalışma Sürelerine Göre Duygusal Emek Ölçeğine İlişkin ANOVA Testi Sonuçları

\begin{tabular}{|c|c|c|c|c|c|c|c|}
\hline \multicolumn{2}{|c|}{$\begin{array}{l}\text { Ölçek ve Alt } \\
\text { Boyutları }\end{array}$} & $\begin{array}{c}\text { Kareler } \\
\text { Toplamı }\end{array}$ & $\begin{array}{c}\text { Serbestlik } \\
\text { Derecesi }\end{array}$ & $\begin{array}{c}\text { Ortalama } \\
\text { Kare }\end{array}$ & $\mathbf{F}$ & $p$ & Fark \\
\hline \multirow{3}{*}{$\begin{array}{l}\text { Duygusal } \\
\text { Emek }\end{array}$} & Gruplar Arası & 1.092 & 4 & 0.273 & & & \\
\hline & Gruplar İçi & 120.556 & 232 & 0.520 & 0.525 & 0.717 & - \\
\hline & Toplam & 121.648 & 236 & & & & \\
\hline \multirow{3}{*}{$\begin{array}{l}\text { Yüzeysel } \\
\text { Rol } \\
\text { Yapma }\end{array}$} & Gruplar Arası & 2.284 & 4 & 0.571 & & & \\
\hline & Gruplar İçi & 279.088 & 232 & 1.203 & 0.475 & 0.754 & - \\
\hline & Toplam & 281.372 & 236 & & & & \\
\hline \multirow{3}{*}{$\begin{array}{l}\text { Derinden } \\
\text { Rol } \\
\text { Yapma }\end{array}$} & Gruplar Aras1 & 2.368 & 4 & 0.592 & & & \\
\hline & Gruplar İçi & 310.589 & 232 & 1.339 & 0.442 & 0.778 & - \\
\hline & Toplam & 312.957 & 236 & & & & \\
\hline \multirow{3}{*}{$\begin{array}{l}\text { Doğal } \\
\text { Duygular }\end{array}$} & Gruplar Aras1 & 1.625 & 4 & 0.406 & & & \\
\hline & Gruplar İçi & 64.709 & 232 & 0.279 & 1.457 & 0.216 & - \\
\hline & Toplam & 66.335 & 236 & & & & \\
\hline
\end{tabular}

Tablo 11'e bakıldığında öğretmenlerin görev yaptıkları okuldaki çalışma sürelerine göre duygusal emek ile yüzeysel rol yapma, derinden rol yapma ve doğal duygular alt boyutlarında istatistiksel olarak anlamlı bir farklılık olmadığı belirlenmiştir $(\mathrm{F}=.525 ; p>.05)$. Buna göre öğretmenlerin okullarındaki çalışma süresinin duygusal emek davranışlarına yönelik bir fark oluşturmadığı söylenebilir. Ayrıca buna paralel olarak duygusal emeğin alt boyutlarındaki davranışları yerine getirmede yine farklılık oluşmadığı görülmektedir.

\section{Sendika Üyeliği}

Sendika üyeliği değişkenine göre öğretmenlerin duygusal emek düzeylerini belirlemek için yapılan $t$ Testi sonuçlarına ilişkin bulgular Tablo 12 'de sunulmuştur.

Tablo 12. Öğretmenlerin Sendika Üyeliğine Göre Duygusal Emek Ölçeğine İlişkin $t$ Testi Sonuçları

\begin{tabular}{llcccccc}
\hline $\begin{array}{l}\text { Ölçek ve Alt } \\
\text { Boyutları }\end{array}$ & $\begin{array}{l}\text { Sendika } \\
\text { Üyeliği }\end{array}$ & N & $\begin{array}{l}\text { Aritmetik } \\
\text { Ortalama }\end{array}$ & $\begin{array}{c}\text { Standart } \\
\text { Sapma }\end{array}$ & Sd & T & \multirow{2}{*}{$\boldsymbol{P}$} \\
\hline Duygusal & Var & 141 & 3.23 & 0.73 & 235 & 0.416 & 0.678 \\
Emek & Yok & 96 & 3.19 & 0.69 & & & \\
\hline Yüzeysel & Var & 141 & 2.37 & 1.13 & 235 & 0.909 & 0.364 \\
Rol Yapma & Yok & 96 & 2.24 & 1.02 & & & \\
\hline Derinden & Var & 141 & 3.59 & 1.15 & 235 & 0.138 & \multirow{2}{*}{0.891} \\
Rol Yapma & Yok & 96 & 3.57 & 1.15 & & & \\
\hline Doğal & Var & 141 & 4.46 & 0.57 & 235 & -1.741 & 0.083 \\
Duygular & Yok & 96 & 4.57 & 0.45 & & & \\
\hline
\end{tabular}


Tablo 12 incelendiğinde öğretmenlerin sendika üyeliğine göre duygusal emek davranışını gerçekleştirme düzeylerini belirmek için yapılan $t$ Testi sonuçlarına göre duygusal emek ile alt boyutları olan yüzeysel rol yapma, derinden rol yapma ve doğal duygular davranışlarında istatiksel olarak anlamlı bir farklılık bulunamamıştır $(\mathrm{t}=.416 ; p>.05)$. Buna göre öğretmenlerin sendika üyeliğinin olup olmaması duygusal emek davranışında anlamlı bir fark oluşturmamaktadır.

\section{Sonuç ve Tartışma}

Araştırmanın birinci alt problemine ilişkin sonuçlara bakıldığında ilkokul ve ortaokul öğretmenlerin duygusal emek davranışını gerçekleştirme düzeylerinin orta düzeyde olduğu sonucuna ulaşılmıştır. Alanyazında Bıyık (2014), Mavi (2015), Akbaş (2016), Ertürk, Keskink1lıç-Kara ve Zafer-Güneş (2016), Demircan ve Turunç (2017), Cingöz (2018) ve Moran'ın (2018) yapmış oldukları çalışmalarda da öğretmenlerin duygusal emekleri düzeylerinin orta düzeyde olduğu görülmekte ve bu bulgular da araştırma sonucu ile tutarlılık göstermektedir. Duygusal emeğin alt boyutlarına ilişkin sonuçlara göre öğretmenlerin yüzeysel rol yapma seviyelerinin düşük düzeyde olduğu belirlenmiştir. Araştırmanın bu sonucunun Beğenirbaş ve Meydan (2012), Yılmaz, Altınkurt, Güner ve Şen (2015), Demircan ve Turunç (2017), Alev ve Bozbayındır (2018), Erken (2018), Özdemir ve Koçak (2018), Şahin (2018) ve Yılmaz-Daban'ın (2018) araştırma sonuçları ile tutarlı olduğu görülmektedir. Bununla birlikte öğretmenlerin yüzeysel rol yapma davranışlarının orta düzeyde olduğunu belirleyen araştırmalar da bulunmaktadır (Akbaş, 2016; Cingöz, 2018; Mavi, 2015; Moran, 2018). Ayrıca Bakar (2018) ve Polatkan (2016), araştırmalarında öğretmenlerin en çok yüzeysel rol yapma davranışını sergilediklerini ortaya koymuştur. Öğretmenlerin derinden rol yapma davranışını gerçekleştirme düzeylerinin yüksek olduğu da belirlenmiştir. Yılmaz, Altınkurt, Güner ve Şen (2015), Polatkan (2016), Demircan ve Turunç (2017) ve Bakar'ın (2018) araştırma sonuçları, çalışmanın bu sonucunu destekler niteliktedir. Bakar (2018) ve Polatkan (2016), öğretmenlerin en az derinlemesine rol yapma davranışını sergilediklerini belirtmesine rağmen öğretmenlerin derinden rol yapma davranışlarını orta (Akbaş, 2016; Beğenirbaş ve Meydan; 2012; Erken, 2018) ve yüksek düzeyde olduğunu belirleyen araştırmalar da (Alev ve Bozbayındır, 2018; Cingöz, 2018; Mavi, 2015; Moran, 2018; Özdemir ve Koçak, 2018; Şahin, 2018; Yılmaz-Daban, 2018) bulunmaktadır. Öğretmenlerin doğal duygular davranış düzeyinin ise çok yüksek düzeyde olduğu belirlenmiştir. 
Araştırmanın bu sonucu Beğenirbaş ve Meydan (2012), Yılmaz, Altınkurt, Güner ve Şen (2015), Alev ve Bozbayındır (2018), Cingöz (2018), Moran (2018), Erken (2018), Özdemir ve Koçak (2018), Şahin (2018), Y11maz-Daban'ın (2018) araştırma sonuçları ile tutarlık göstermektedir. Bununla birlikte Demircan ve Turunç'un (2017) araştırmasında öğretmenlerin doğal duygular düzeylerinin orta seviyede olduğu belirlenmiştir.

Araştırmanın ikinci alt problemine ilişkin sonuçlarında ise öğretmenlerin duygusal emek düzeylerinin cinsiyete göre anlamlı bir farklılık gösterdiği belirlenmiştir. Erkek öğretmenlerin duygusal emek davranışını yerine getirme düzeylerinin kadın öğretmenlerden daha yüksek olduğu ortaya konmuştur. Ayrıca yüzeysel rol yapma ve doğal duygular boyutlarında anlamlı farkl11ık olduğu belirlenmiştir. Erkek öğretmenlerin yüzeysel rol yapma davranışını gerçekleştirme düzeylerinin kadın öğretmenlere göre ve kadın öğretmenlerin ise doğal duygular davranışını gerçekleştirme düzeylerinin erkek öğretmenlere göre daha yüksek olduğu ortaya çıkmıştır. Araştırmanın bu sonucu Bıyık (2014), Yılmaz ve arkadaşları (2015), Ertürk ve arkadaşları (2016), Akbaş (2016), Cingöz (2018), Erken (2018), Moran (2018) ve Y11maz-Daban (2018) araştırma sonuçları ile tutarlık göstermektedir. Polatkan (2016) ise araştırmasında öğretmenlerin duygusal emek düzeylerinin cinsiyete göre farklılaşmadığını belirlemiştir. Bıyık (2014) ve Ertürk ve arkadaşlarının (2016) araştırmalarında erkek öğretmenlerin duygusal emek düzeylerinin kadın öğretmenlere göre daha yüksek olduğunu belirlerken Y1lmaz ve arkadaşları (2015), Akbaş (2016), Cingöz (2018), Moran (2018), Erken (2018) ve Y1lmaz-Daban (2018) da erkek öğretmenlerin yüzeysel rol yapma davranışını sergileme düzeylerinin kadın öğretmenlere göre daha yüksek olduğunu tespit etmişlerdir. Cingöz (2018) ve Erken (2018) erkek öğretmenlerin derinden rol yapma düzeylerinin kadın öğretmenlere göre daha yüksek olduğunu belirtirken Cingöz (2018) kadın öğretmenlerin doğal duygu düzeylerinin erkek öğretmenlere göre daha yüksek olduğunu saptamıştır.

Öğretmenlerin yaşlarına göre duygusal emek davranışı ile yüzeysel rol yapma davranışında anlamlı bir farklılık olduğu belirlenmiştir. Buna göre 41 yaş ve üzerinde olan öğretmenlerin duygusal emek davranışı ile yüzeysel rol yapma davranışını gerçekleştirme düzeylerinin $20-25$ ve $31-35$ yaş aralığındaki öğretmenlere göre daha yüksek olduğu ortaya konmuştur. Ertürk ve arkadaşlarının (2016) araştırma sonuçlarına göre öğretmenlerin duygusal emek davranışlarının yaş değişkenine göre farklılaştığı belirlenmiştir. Buna 
göre 41 yaş ve üzerinde olan öğretmenlerin duygusal emek davranışını gerçekleştirme düzeyinin 31-40 yaş ve 31 yaş ve altı grubundaki öğretmenlere göre daha yüksek olduğu sonucuna ulaşılmıştır. Bıyık (2014) araştırmasında öğretmenlerin yaşlarına göre duygusal emek düzeylerinin farklılaştığını belirlemiştir. Buna göre 41-50 ve 51-60 yaş aralığındaki öğretmenlerin duygusal emek algıları 20-30 ve 31-40 yaş aralığındaki öğretmenlere göre daha yüksek olduğu sonucuna ulaşılmıştır. Polatkan (2016) araştırmasında öğretmenlerin derinden rol yapma davranışlarının yaşa göre farklılık gösterdiğini belirlemiş̧ir. Buna göre 46 yaş ve üzeri öğretmenlerin derinden rol yapma davranışlarının 30 yaş ve altındaki öğretmenler ile 41-45 yaş aralığındaki öğretmenlere göre daha yüksek olduğu sonucuna ulaşmıştır. Cingöz (2018) araştırmasında 56 yaş ve üzerindeki öğretmenlerin derinden rol yapma davranış düzeylerinin 20-25, 26-30, 31-35, 36-40, 41-45, 46-50 yaş aralıklarındaki öğretmenlere göre daha yüksek olduğunu belirlemiştir. Buna göre yaşı daha büyük olan öğretmenlerin duygusal emek davranışlarını gerçekleştirme düzeylerinin daha yüksek olduğu görülmüştür ve araştırmanın bu sonucu alanyazındaki araştırma sonuçları ile tutarlık göstermektedir. Ancak Erken (2018) ve Moran (2018) ise öğretmenlerin duygusal emek algılarının yaş değişkenine göre farklılık göstermediği sonucuna ulaşmıştır.

Öğretmenlerin medeni durumlarına göre duygusal emek davranışı ile yüzeysel rol yapma, derinden rol yapma ve doğal duygular davranışlarını gerçekleştirme düzeylerinde anlamlı bir farklılık olmadığı belirlenmiştir. Araştırmanın bu sonucu Polatkan (2016), Erken (2018), Moran (2018) ve Yılmaz-Daban'ın (2018) sonuçları ile tutarlılık göstermektedir. Bununla birlikte Bıyık (2016) araştırmasında öğretmenlerin duygusal emek düzeylerinin medeni duruma göre farkl11ık gösterdiğini ve evli öğretmenlerin duygusal emek davranışlarının bekâr öğretmenlere göre daha yüksek olduğunu belirlemiştir. Yılmaz ve arkadaşları (2015) ve Cingöz (2018) ise evli öğretmenlerin yüzeysel rol yapma davranışını gerçekleştirme düzeylerinin bekâr öğretmenlere oranla daha yüksek olduğunu belirlemiştir.

Öğretmenlerin duygusal emek düzeylerinin eğitim durumuna göre duygusal emek davranışının yüzeysel rol yapma ve derinden rol yapma alt boyutlarında anlamlı bir farklılık oluşturmadığı ancak doğal duygular alt boyutunda anlamlı farkl1lık oluşturduğu belirlenmiştir. Buna göre, lisansüstü eğitim almış öğretmenlerin doğal duyguları sergileme düzeylerinin lisans mezunu öğretmenlere göre daha yüksek olduğu belirlenmiştir. Ertürk ve 
arkadaşları (2016), Bıyık (2014), Polatkan (2016), Moran (2018) ve Erken (2018), öğretmenlerin eğitim durumuna göre duygusal emek düzeylerinin farklılık göstermediğini belirlemiştir. Buna göre araştırmanın bu sonucu alanyazındaki sonuçlarla uyumlu değildir.

Öğretmenlerin görevli oldukları okul türüne göre duygusal emek davranışı; yüzeysel rol yapma ve derinden rol yapma davranışlarında anlamlı bir farklılık ortaya çıkmıştır. Bu sonuca göre ilkokullarda görev yapan öğretmenlerin ortaokullarda görev yapan öğretmenlere göre duygusal emek davranışı ile yüzeysel rol yapma ve derinden rol yapma davranışlarını gerçekleştirme düzeylerinin daha yüksek olduğu belirlenmiştir. Yılmaz (2015) ise ilkokul öğretmenlerinin yüzeysel rol yapma, doğal duyguları ve derinden rol yapma düzeylerinin lise öğretmenlere göre daha yüksek olduğunu ortaya koymuştur. Ertürk ve arkadaşlarının (2016) araştırmasında öğretmenlerin görev yaptıkları okul türüne göre duygusal emek davranışlarının farklılık gösterdiği ve ilkokullarda görev yapan öğretmenlerin duygusal emek davranışını gerçekleştirme düzeyinin ortaokul ve liselerde görev yapan öğretmenlere göre daha yüksek olduğu saptanmıştır. Moran (2018), ilkokullarda çal1şan öğretmenlerin ortaokul öğretmenlerine göre samimi davranış sergileme düzeylerinin daha yüksek olduğunu belirlemiştir. Buna göre yaşı daha büyük olan öğretmenlerin duygusal emek davranışlarını gerçekleştirme düzeylerinin daha yüksek olduğu görülmüştür ve araştırmanın bu sonucu alanyazındaki araştırma sonuçları ile tutarlık göstermektedir. Ancak Erken (2018) ve Moran (2018) ise öğretmenlerin duygusal emek algılarının yaş değişkenine göre farkl11ık göstermediği sonucuna ulaşmıştır.

Öğretmenlerin meslekî kıdemlerine göre duygusal emek davranışında ve yüzeysel rol yapma alt boyutunda anlamlı bir farkl1lık olduğu bulunmuştur. 20 yıl ve üzeri meslekî kıdeme sahip öğretmenlerin duygusal emek davranışını gerçekleştirme düzeylerinin 1-5 yıl ve 6-10 yıl arası meslekî kıdeme sahip öğretmenlere göre daha yüksek olduğu belirlenmiştir. Yüzeysel rol yapma davranışında da 20 yıl ve üzeri meslekî kıdeme sahip öğretmenlerin 1-5 yı1 ve 6-10 yıl arası meslekî kıdeme sahip öğretmenlere nazaran daha yüksek olduğu belirlenmiştir. Ertürk ve arkadaşlarının (2016) araştırmasında öğretmenlerin duygusal emek davranışlarının meslekî kıdeme göre anlamlı farklılık gösterdiği belirlenmiştir. Buna göre 16 y1l ve üzerinde meslekî k1deme sahip öğretmenlerin duygusal emek davranışını gerçekleştirme düzeylerinin 1-5, 6-10 ve 11-15 yıl meslekî kıdeme sahip öğretmenlere göre daha 
yüksek olduğu sonucuna ulaşılmıştır. Bıyık (2014) araştırmasında 6-10, 16-20 ile 21 yıl ve üzeri meslekî kıdeme sahip öğretmenlerin duygusal emek düzeylerinin 1-5 yıl arasında meslekî kıdeme sahip öğretmenlere kıyasla daha yüksek olduğunu belirlemiştir. Akbaş (2016), 21 y1l ve üzeri meslekî kıdeme sahip öğretmenlerin yüzeysel rol yapma düzeylerinin 1-10 yıl arası meslekî kıdeme sahip öğretmenlere göre daha yüksek olduğunu tespit etmiştir. Cingöz (2018), araştırmasında 41 yıl ve üzeri meslekî kıdem sahip öğretmenlerin 16-20 yıl arasında meslekî kıdeme sahip öğretmenlere göre derinden rol yapma davranış düzeylerinin daha yüksek olduğunu belirlemiştir. Moran (2018) da 21 yıl ve üzeri meslekî kıdeme sahip öğretmenlerin yüzeysel rol yapma davranışlarının 16-20 yıl arası meslekî kıdeme sahip öğretmenlere göre daha yüksek olduğu sonucuna varmıştır. Yukarıdaki araştırma sonuçlarının bu araştırmanın sonucu ile büyük oranda benzerlik gösterdiği söylenebilir. Buna rağmen Polatkan (2016), Erken (2018) ve Y1lmaz-Daban (2018) ise araştırmasında öğretmenlerin duygusal emek düzeylerinin meslekî kıdeme göre farklılaşmadığını ifade etmişlerdir.

Öğretmenlerin duygusal emek ile yüzeysel rol yapma, derinden rol yapma ve doğal duygular düzeylerinin görev yaptıkları okuldaki çalışma sürelerine göre anlamlı bir farklılık oluşturmadığı belirlenmiştir. Ancak Akbaş'ın (2016) araştırmasında öğretmenlerin görev yaptıkları okuldaki çalışma süresine göre duygusal emek algılarının farklılaştığı belirlenmiş ve 1-3 y1l süresince kendi okulunda görev yapan öğretmenlerin derinden rol yapma düzeylerinin 4-6 yıl arasındaki öğretmenlere göre daha yüksek olduğu ortaya konulmuştur.

Öğretmenlerin sendika üyeliğine göre duygusal emek davranışı ile yüzeysel rol yapma, derinden rol yapma ve doğal duygular davranışlarında anlamlı bir farklılık bulunamamıştır.

\section{Öneriler}

$\mathrm{Bu}$ araştırma sonucunda öneriler şöyledir:

- $\mathrm{Bu}$ araştırma, tarama modelinde gerçekleştirilmiş olup gelecek araştırmalarda nitel araştırma tekniği kullanılarak öğretmenlerin duygusal emek davranışlarının derinlemesine incelenmesine yardımcı olabilir.

- Bu araştırmada ilkokul öğretmenlerinin duygusal emek davranışını daha yoğun bir şekilde gerçekleştirdikleri saptanmıştır. İlkokul öğretmenlerinin duygusal emek konusundaki becerilerinin uygulamalı 
atölye çalışmaları ile ortaokul ve lise seviyesindeki öğretmenlerle paylaşmasına imkân verilebilir.

- Araştırmaya ilkokul ve ortaokul öğretmenleri katılmıştır. Yalnızca lise öğretmenlerinin örneklem alındığı ya da tüm okul türlerinde görev yapan öğretmenlerin yer aldığı araştırmalar gerçekleştirilebilir.

- Bu araştırma sonucunda tecrübeli öğretmenlerin duygusal emek davranışını daha yoğun gerçekleştirdikleri belirlenmiştir. Genç öğretmenler için öğretmenlik mesleğinin gerektirdiği duygusal emek davranışlarını kazanmaları adına tecrübeli öğretmenlerle belirli sürelerde birlikte ders verebilecekleri mentorlük programları düzenlenebilir. Tecrübeli öğretmenlerin yapacağı bu mentorlük ile genç öğretmenler öğretimde duygusal emek davranışlarını daha yararlı şekilde kullanabileceklerdir.

- Duygusal emek ve örgütsel bağl1l1k, örgütsel destek, öğretim performansı kavramları arasındaki ilişkilerin incelendiği araştırmalar gerçekleştirilebilir.

\section{Kaynakça}

Akbaş, A. (2016). Öğretmenlerin örgütsel politika algzlart ile duygusal emek düzeyleri arasındaki ilişki. Yayımlanmamış yüksek lisans tezi, Uşak Üniversitesi Sosyal Bilimler Enstitüsü.

Alev, S. ve Bozbayındır, F. (2018). Öğretmenlerin genel öz yeterlilik algıları, izlenim yönetimi taktikleri kullanımları ve duygusal emek davranışları arasındaki ilişki. Kırşsehir Eğitim Fakültesi Dergisi, 19(3), 1788-1807.

Argon, T. (2015). Öğretmenlerin sahip oldukları duygu durumlarının okul yöneticilerinin dikkate alıp almamalarına ilişkin görüşleri. Abant İzzet Baysal Üniversitesi Ĕ̈itim Fakültesi Dergisi, 15(1), 377-404.

Argon, T. ve Yılmaz, Ö. (2019). Öğretmenlerin öğretim duygu durumları ile örgütsel destek algıları arasındaki ilişki. 14. Uluslararası Eğitim Bilimleri Kongresi Tam Metin Bildiri Kitabı içinde (256-261). İzmir: Orta Doğu Teknik Üniversitesi.

Aydın, İ. (2016). Eğitimde duygusal emek. I. Ünal ve Y. Koçak Usluel, (Ed.), Prof. Dr. Mustafa Aydın'a Armağan içinde (169-183). Ankara: Gazi Kitapevi.

Bakar, H. (2018). Lise ögretmenlerinin duygusal emek davranışı ile öznel iyi oluş düzeyleri ve aralarındaki ilişskilerin incelenmesi: Kastamonu ili örneği. Yayımlanmamış yüksek lisans tezi, Kastamonu Üniversitesi Eğitim Bilimleri Enstitüsü.

Basım, H. N. ve Beğenirbaş, M. (2012). Çalışma yaşamında duygusal emek: Bir ölçek uyarlama çalışması. Yönetim ve Ekonomi: Celal Bayar Üniversitesi İktisadi ve İdari Bilimler Fakültesi Dergisi, 19(1), 77-90.

Beğenirbaş, M. ve Meydan, C. H. (2012). Duygusal emeğin örgütsel vatandaşlık davranışıyla ilişkisi: öğretmenler üzerinde bir araştırma. Gazi Üniversitesi İktisadi ve İdari Bilimler Fakültesi Dergisi, 14(3), 159-181. 
Bıyık, Y. (2014). Duygusal emek ile örgütsel vatandaşlık davranışı iliş̧isi: bir araştırma. Yayımlanmamış yüksek lisans tezi, Gazi Üniversitesi Sosyal Bilimler Enstitüsü.

Brotheridge, C. ve Lee, R. (2003). Development and validation of the emotional labour. Journal of Occupational and Organizational Psychology, 76(3), 365-379.

Bursalığlu, Z. (2015). Okul yönetiminde yeni yapı ve davranış. Ankara: Pegem Akademi.

Cingöz, E. (2018). Öğretmenlerin duygusal emek davranışları ile tükenmişlikleri arasındaki iliş̧kinin incelenmesi. Yayımlanmamış yüksek lisans tezi, Eskişehir Osmangazi Üniversitesi Eğitim Bilimleri Enstitüsü.

Demircan, P. ve Turunç, Ö. (2017). İş-aile çatışması-duygusal emek ilişkisinde lider desteğinin rolü: eğitim üzerine bir araştırma. İstanbul Gelişim Üniversitesi Sosyal Bilimler Dergisi, 4(1), 41-76.

Diefendorff, J. M., Croyle, M. H. ve Gosserand, R. H. (2005). The dimensionality and antecedents of emotional labor strategies. Journal of Vocational Behavior, 66(2) 339-357.

Erken, S. A. (2018). Lise öğretmenlerinin duygusal emek davranışları ile tükenmişlik düzeyleri arasındaki ilişkinin incelenmesi. Yayımlanmamış yüksek lisans tezi, Marmara Üniversitesi Eğitim Bilimleri Enstitüsü.

Ertürk, A., Keskinkılıç Kara, S. B. ve Zafer-Güneş, D. (2016). Duygusal emek ve psikolojik iyi oluş: Bir yordayıcı olarak yönetsel destek algısı. Abant İzzet Baysal Üniversitesi Ĕgitim Fakültesi Dergisi, 16(4), 1723-1744.

Fein, A. H. ve Isaacson, N. S. (2009). The emotion work of leaders in school shooting sites. American Behavioral Scientist, 52(9), 1327-1346.

Hochschild, A. R. (1979). Emotion work, feeling rules, and social structure. American Journal of Sociology, 85(3), 551-575.

Hochschild, A. R. (1983). The managed heart: Commercialization of human feeling. Berkeley: University of California Press.

Hochschild, A. R. (2003). The managed heart: Commercialization of human feeling (2. bask1). Berkeley: University of California Press.

Karasar, N. (2000). Bilimsel araştırma yöntemleri-kavramlar, ilkeler, terimler (10. baskı). Ankara: Nobel Yayın Dağıtım.

Mavi, D. (2015). Öğretmen görüşlerine göre duygusal emek, iş özellikleri ve iş akışı arasındaki ilişki (Elbistan ilçesi örneği). Yayımlanmamış yüksek lisans tezi, Zirve Üniversitesi Sosyal Bilimler Enstitüsü.

Moran, C. (2018). Ilköğretim kurumlarındaki öğretmenlerin duygusal emek davranışları ile yaşam doyum düzeyleri arasındaki ilişki. Yayımlanmamış yüksek lisans tezi, Çanakkale Onsekiz Mart Üniversitesi Eğitim Bilimleri Enstitüsü.

Özdemir, M. ve Koçak, S. (2018). Predicting teacher emotional labour based on multi-frame leadership orientations: a case from Turkey. Irish Educational Studies, 37(1), 69-87.

Polatkan, N. N. (2016). Ortaokul öğretmenlerinin duygusal emek davranışlart ile iş doyumları arasındaki ilişki. Yayımlanmamış yüksek lisans tezi, Adnan Menderes Üniversitesi Sosyal Bilimler Enstitüsü.

Rafaeli, A. ve Sutton, R. I. (1989). The expression of emotion in organizational life. Research in Organizational Behavior, 11(1), 1-42. 
Şahin, M. (2018). Women leadership and its effect on teachers' emotional labor in Turkish high schools. Quality \& Quantity, 52, 1445-1454.

Yılmaz, K., Altınkurt, Y., Güner, M. ve Şen, B. (2015). The relationship between teachers' emotional labor and burnout level. Eurasian Journal of Educational Research, 59, 75-90.

Y1lmaz-Daban, B. (2018). Ortaokul ögretmenlerinin duygusal emek ile tükenmişlik düzeyleri arasındaki ilişkinin incelenmesi. Yayımlanmamış yüksek lisans tezi, Recep Tayyip Erdoğan Üniversitesi Sosyal Bilimler Enstitüsü. 